\title{
APPLYING EDMODO IN IMPROVING STUDENT ACHIEVEMENT IN TEACHING ENGLISH AS FOREIGN LANGUAGE FOR ELEVENTH GRADER IN MAN 1 AMBON
}

\author{
Rohib Adrianto Sangia \\ rohib@kemenag.go.id
}

\begin{abstract}
The goal of this research is to determine of the implementation of Edmodo in learning English as foreign language for the eleventh grader in MAN 1 Ambon. The problems of this research are how Edmodo is implemented by the teachers in learning English as foreign language (EFL) in order to gain the better results of students learning achievement and what the problems around using Edmodo are found and solved by the teachers. It is a classroom action research based on qualitative-research. Research's data is collected by doing class observation, filling the questionnaire, and test in two cycles. The first cycle results the average score that students can accomplish is 44.38 points which is below from the standard of minimum accomplishment (SMA) that is 75 points and there are only $12 \%$ of the students can accomplish the test. By applying Edmodo in the second cycle, the average mark of the students is touching 82.61 points with the conclusion that Edmodo succeed increases students' achievements. The difficulties that are encountered in applying Edmodo in digital class are the availability of the hardware from the internet infrastructure to personal computer or smartphone of the students and the proficiency of students and teachers in using Edmodo.
\end{abstract}

Keywords: Teaching English as foreign language, Edmodo, Students' achievements

\section{INTRODUCTION}

Chapelle (2003: 2) claims that language learning and information technology from the beginning of millennium has strong emotional bounding and completing each other. This is a reason why there are so many innovations and creations of new software in the field of linguistics that gives the students can independently learning and can be done massively in long distance. The prominent aspect that can be perceived is the process in assessing language skills by using modern computerization technology.

Practicality principle in language assessments particularly in assessing listening and reading skills gives opportunity in developing evaluation media to the digital approach, since evaluation process for instance a test, is a small part but it is meaningful of a learning process (Brown, 2001: 402).

Reading skill is a language skill with focusing in language acquisitions. For that reason, reading comprehension need to be evaluated in order to measure the output that can be demonstrated by the students with the result that they can reach achievement level. Heaton (1989: 107) suggests several form of test in measuring students' learning achievements in mastering reading skills. The forms of the test are multiple-choice, truefalse, matching, arranging scramble sentences or paragraphs, to short questions.

In the actual drill in regular classroom, there are several application with various platform has been developed by the experts, from the stand-alone based application to more 
composite application. Learning system has been integrating the whole part of the learning process from the planning process until evaluation process that using whether using intranet or internet is known as learning management software (Amiroh, 2012: 1) or with another term that popular as digital class. These kind of learning management are utilizing digital media such as Edmodo, Moodle, even more Schoology that has been highly recommended by Juliani (2015: 31)

Edmodo is a kind of education website that has been founded by Jeff'O Hara in 2008 that facilitated the active and creative learning that can attract the students' attention. It is a tool to develop digital class in the concept of blended learning. Rismayanti (2013: 3) convinces that Edmodo is exceedingly secure to be applied for teachers and students. The nature of Edmodo which is website based application makes the data storage is kept inside its server so that it can be said safe and accessible every time by using internet connection. For the education institutions, it offers more opportunity in order to facilitate the collaboration inter-personal, inter-institutional, inter-local, to inter-continental, in order to present the best quality of education services to the students. Since it is a website, this media is advantageous in monitoring the students' attitude in cyberspace, so that it can reduce the negative influence of internet facilities.

Edmodo as a website, need internet connection by its user. The user can login as teachers, students, or the parents with the simplicity to exchange the status based on the necessity. The user can access Edmodo by using common tools in accessing internet from gadget to personal computer (PC). Edmodo bounces the distinguishing teaching experience in digital class from the planning, executing, till doing testing. In the planning process, teachers can arrange learning schedule, check the timeline, and get massage or reminder as the consideration to determine the best learning scenario. Besides that, library feature assists teachers in preparing teaching material efficiently, effectively so it can be accessed by students just in time.

The research that employing Edmodo has been developed since it is published. For the domestic research with the high school students as the subjects, there are several publication of research among others Noviana, Rufinus, and Bunau (2015), Hastomo (2016), and the latest Adnan, Ohoiwutun, and Shalehuddin (2016), whereas their research methodology are using pre-experimental design in applying Edmodo to teach EFL. By referring from those publications, this research is trying to employ classroom action research as based methodology with focusing in solving two main problems. The problems are how Edmodo is implemented by the teachers in learning EFL in order to gain the better results of students learning achievement and what the problems around using Edmodo are found and solved by the teachers.

\section{LEARNING ACTIVITY}

Learning activity that is elaborated in this section focuses on the process of learning a second cycle that emphasizes the application of Edmodo to the student. Before learning activity, researcher prepared several aspects to accommodate Edmodo in the classroom. There are some important aspects that must be considered in this process. The first aspect lies in the human resources aspects of both users and managers. And additionally the second aspects are required facilities and infrastructure to apply Edmodo so that it can work as expected. In terms of human resources, the student is the main actor in Edmodo. 
Students are considered as the user where they are accessing Edmodo in order to receive learning source and learning assessment. In the meantime, teachers act as manager, where teachers facilitate students to access learning resources and providing authentic assessment to students.

To understand Edmodo, it is important for a teacher to learn the basic techniques of using Edmodo in position of teachers, students, and parents. Many things can be done by a teacher to acquire the skills in using Edmodo, from self-taught, learning from books, tutorials, studied to peers or ask questions in the discussion forum of digital learning in the internet media until attending training that organized by the institution or professional organization. After that process, the teachers can help students to run Edmodo, but if it is needed, students can access the help centre on the site Edmodo to seek solutions of the problems. Moreover, language interface in the help centre is in English, it can really help students, in applying their English language skills particularly in reading comprehension.

To provide Internet connections, the researcher decided to use the internet connection via a mobile network which was connected to the modem Vodafone Huawei on 4G internet connection and it is shared by using two routers are D-Link DGN1000 and TPLink MR3020 as the host for the modem. It was expected can decrease the base stations of mobile internet service providers working load and reduce students' expenditure in buying a new modem for who do not have to support the learning process using Edmodo media. For hardware such as PCs, researcher required the student to bring a laptop device or smart phone that has internet browser at the time of learning activities carried out.

When the class started, researcher inspected the students' preparations. There were about three students who did not bring the device to access Edmodo with the reason they did not have the device or find a friend or relative who wants to lend. Therefore, researcher provided a solution by placing the student with a seatmate who had devices so that they could share. Additionally, there were students who had not registered, so they immediately were ordered to register an Edmodo account and guided by the friends who signed up previously.

On learning activities, researcher began to guide them to interact virtually by posting material so they could make a discussion. Researcher as teachers also provided direction, guidance and warnings about the student's behaviour issues in cyberspace. Learning activity by using Edmodo was dominated by accomplishing the tasks that posted on Edmodo. After finishing the tasks, students and teachers discussed and evaluated the results together by utilizing learning outcomes analysis features that had been provided by Edmodo.

After learning activity, students were given extra time to answer the polling that posted by researcher as questionnaires in order to measure the students' motivation in learning with using Edmodo. The students did not mind to do so more over they expressed their enthusiasm to do this kind of learning activity in the next meeting. Positive responses came from some fellow teachers who monitored the learning process, consequently that they were intended to plan doing similar thing in their class.

\section{METHODOLOGY}

This research which is based on classroom action research is regarded by Mettetal (2003: 3) has superiority in order to find out the best solution in helping students in 
increasing their learning achievement and effectively in improving teaching methodology and strategy of a teacher. In engaging this methodology, there are four fundamental steps that should be passed by the researcher. Those steps are planning, acting, observing and reflecting, which are one whole teaching cycle (Kemmis, McTaggart, \& Nixon, 2014: 9). A teaching cycle cannot approve something until there is an alteration in the next teaching cycle.

Planning is the leading step in doing action research. In the planning process, a researcher is trying to find the problems that encountered in teaching process. After finding the problems, it should be preliminary discussed about the reasonable alternative solutions based on the theories of teaching. Then, the most acceptable solutions should be applied in order to find out the results. A plan should be made dynamically, independently and adaptability to the unanticipated obstacles by the researcher (Kemmis et al., 2014: 100). Planning is beneficial for a researcher as the grounding in doing an action properly so that a problem can be solved effectively and efficiently.

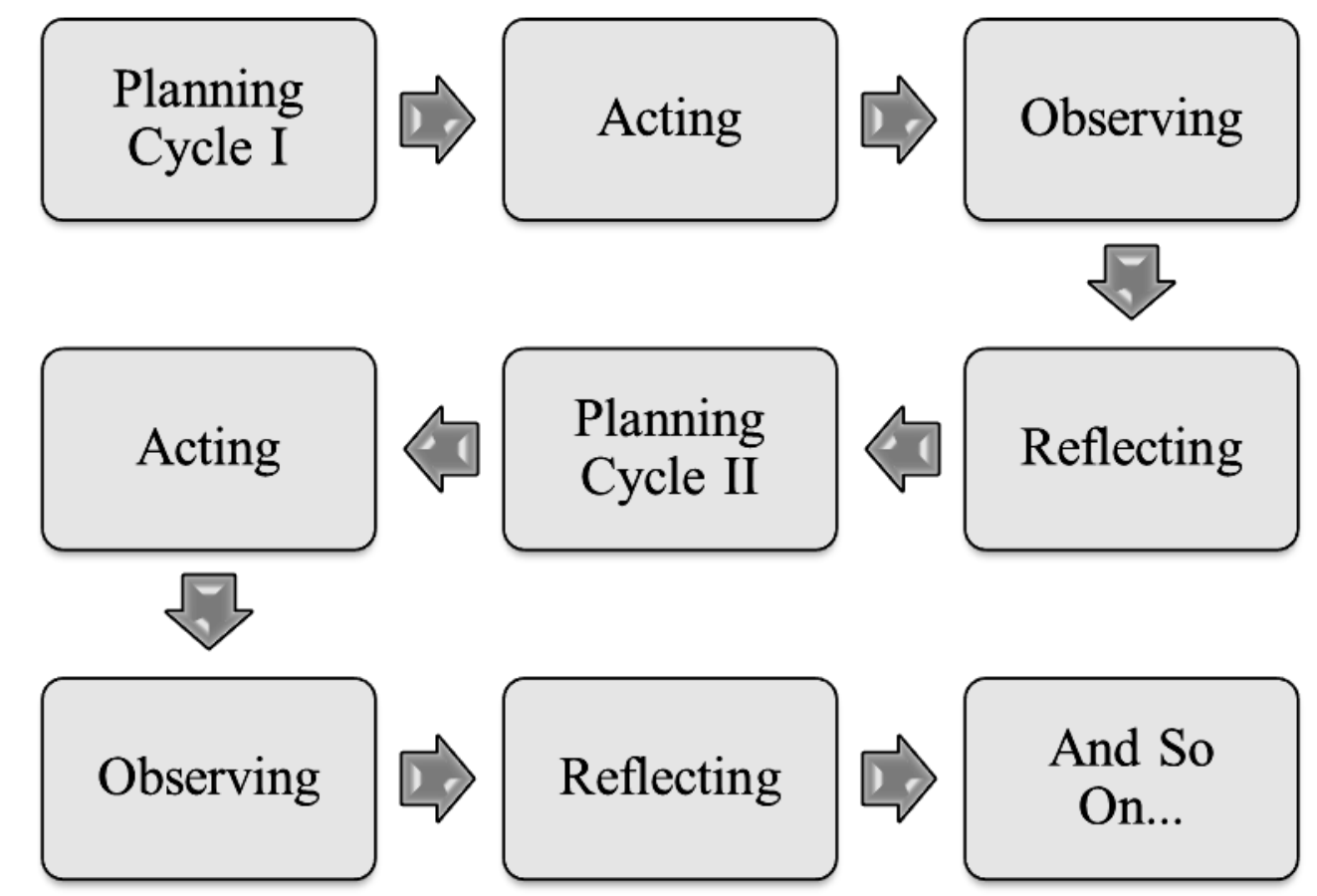

Cycle of Classroom Action Research (Kemmis et al., 2014: 19)

Acting is the furtherance of the planning step. Actually, an action is conducted by considering a careful planning based on the background of the problem (Kemmis et al., 2014: 18). From the acting process, there are many things can be found around the problems, thus a researcher can applying a method to the collected data so it is expected can solve the problems as well as increase the teacher's professional teaching skills

Action process and observation process are two things that are occurred simultaneously when there is a teaching process in a classroom. This process in committed with purpose to collect all the evidence as the raw data form an treatment so that it is examined directly by a researcher (Kemmis et al., 2014: 18). Furthermore, the observation 
is deployed carefully in order to find all kinds of problems thus it is documented to take a big picture whether the results give positive or negative output. This is an important process with the intention of making a parameter and data analysis as well as the documentation of research activity, research process and research results.

Reflection is a stage where the researcher is reminding and understanding everything that had occurred and found in previous stages or steps (Kemmis et al., 2014: 18). Reflecting is the determination to recount all the process, risen problems and the obstacles that happened when the treatment is committed to a logical relationship. The main function of this step is concluding the best alternative solutions as the consideration in the future treatment of the next teaching cycle.

This research is conducted in Madrasah Aliyah Negeri 1 Ambon, an Islamic State Senior High School under bow of Ministry of Religion Affairs Republic Indonesia which is located in Ambon, the capital city of Maluku province. The group that is the subject of the research is the eleventh grader from social program consists of 23 students with 12 male students and 11 female students with their age range between 15-17 years old. They are the students with average ability in learning achievements with differences learning environments and backgrounds with the result as they have various experiences in using technology in learning.

There are three main instruments that are applied in order to collect the data to be analysed. They are observation, questionnaire and quiz. Observation sheet is used by the observer in documenting the students' attitude inside the learning process. All of the students' behaviour, attitude, and act when they are in the learning process are the symbols or sketch of students' condition. From the observation sheet, the researcher can define aspects of motivation that students have. In order to get an authentic fact, observation sheet is validated with questioners that has similar aims is to measures the students learning motivations. Questionnaires give meaningful information about their feelings and responds not only during but also after the learning process particularly in the Edmodo sessions. Quizzes have main roles in measuring students' learning achievement based on the learning objectives that are made in corridor of learning substances. There are several quiz formats that are used in order to measure the students' learning achievements that have been validated before.

The data collection is held in the teaching process for observation and quiz. After the teaching process, the students can fill the questionnaires with the medium both papers and Edmodo. The observation results are documented inside the observation sheets that have been guided to the observer in order to facilitate the observer itself. For the questionnaires, it is distributed to the students after the classroom activity in first cycle. In the second cycle, students are guided to participate the pooling that has been posted on Edmodo wall. Every time they fill the questionnaires, they will be guided how to answers the questions with certain period of time.

\section{FINDINGS AND DISCUSSIONS}

In the first cycle, the learning process is held by using conventional media such as student sheets and textbook with conducting inquiry model, where the teacher guides the students to find out the learning objectives. The main activity is reading comprehension of the analytical exposition text. Learning process is dominated with doing the exercises by 
spoken interaction or written assessments, that has closed relation with theories of reading comprehension that are students' understanding text's general information, main idea of the paragraphs and detail information both implicit and explicit that is in the text.

The learning activity in the first cycle is using paper based media such as students' sheet and textbooks. It gives them space for learning and doing exercises about teaching materials and their understanding on the papers. They are distributed and be used by the students. From all series of teaching activities in the first cycle, the data is collected in the instruments.

Students' questionnaires are filled with the statements that are representing indicators of students' motivations based on the learning activities that have been conducted. With the yes-no respond model, the results of questioners' instruments is displayed in the table below.

Questionnaires Summary of the First Cycle

\begin{tabular}{|c|l|c|c|}
\hline \multirow{2}{*}{ No } & \multicolumn{1}{|c|}{ Statements } & \multicolumn{2}{c|}{ Students' Respond } \\
\cline { 3 - 4 } & & Positive & Negative \\
\hline 1. & I am glad to learn EFL & $94 \%$ & $6 \%$ \\
\hline 2. & I come early to the school if there is EFL lesson & $56 \%$ & $44 \%$ \\
\hline 3. & I bring English dictionary when I am studying EFL & $38 \%$ & $63 \%$ \\
\hline 4. & My EFL Teacher is fun & $94 \%$ & $6 \%$ \\
\hline 5. & I'm happy if the EFL teacher cannot attend class & $69 \%$ & $31 \%$ \\
\hline 6. & I can stand for long time in the classroom to learn EFL & $50 \%$ & $50 \%$ \\
\hline 7. & I sat in front when the EFL lessons take place & $38 \%$ & $63 \%$ \\
\hline 8. & I ask the question if I do not understand the EFL lessons & $50 \%$ & $50 \%$ \\
\hline 9. & I am active in learning EFL & $44 \%$ & $56 \%$ \\
\hline 10. & I am still learning even when there are no exams & $56 \%$ & $44 \%$ \\
\hline 11. & I learn when there is exam appointment & $44 \%$ & $56 \%$ \\
\hline 12. & I'm ready when the EFL teacher gives a pop quiz & $44 \%$ & $56 \%$ \\
\hline 13. & I am lazy to go to class when there is EFL tasks & $69 \%$ & $31 \%$ \\
\hline 14. & I know the benefits of learning EFL & $94 \%$ & $6 \%$ \\
\hline 15. & I take note for many things that are important even & $81 \%$ & $19 \%$ \\
\hline 16. & I like learning with this model, because it is not boring & $94 \%$ & $6 \%$ \\
\hline 17. & With this model, I find no difficulty in learning. & $69 \%$ & $31 \%$ \\
\hline 18. & This learning model can increase my concentration & $69 \%$ & $31 \%$ \\
\hline 19. & $\begin{array}{l}\text { I love when the teacher presents the objectives and } \\
\text { benefits of the learning materials }\end{array}$ & $100 \%$ & $0 \%$ \\
\hline 20. & This learning model can measure my accomplishments & $94 \%$ & $6 \%$ \\
\hline & & $\mathbf{6 7 \%}$ & $\mathbf{3 3 \%}$ \\
\hline
\end{tabular}

The table above displays that positive responds is more dominated than negative responds. The results reflect that it can assume that the levels of average of students' motivations are in $67 \%$. It can be concluded that all students are ready to learn with strong 
motivations even though the learning activities is conducted with conventional media such as paper and pen in running the class

It can be supposed that motivations' level in 67\% cannot give significant impact for the students' learning achievements. It signs that there should be an exacting treatment to students in order to escalate the number of average students' motivations. At this point of motivations' level, it describes the levels of participation of students in learning activities and students' effort in fronting the learning difficulties. Thus, there are one third of all students are suffering to solve their learning difficulties and should be helped with better methodology or treatment. In order to validate the questionnaires results, it should be confronted with the observation results.

Observation Results of the First Cycle

\begin{tabular}{|c|l|c|c|}
\hline No & \multicolumn{1}{|c|}{ Indicator } & $\begin{array}{c}\text { Quantity of } \\
\text { Activeness }\end{array}$ & $\begin{array}{c}\text { Quality of } \\
\text { Activeness }\end{array}$ \\
\hline 1. & Determination in carrying out the learning tasks & $73 \%$ & $60 \%$ \\
\hline 2. & Persistence in fronting of difficulties & $80 \%$ & $40 \%$ \\
\hline 3. & Good feelings towards learning EFL & $80 \%$ & $60 \%$ \\
\hline 4. & Independence in learning & $60 \%$ & $40 \%$ \\
\hline 5. & The strong desire to learn EFL & $77 \%$ & $60 \%$ \\
\hline & \multicolumn{1}{|c|}{ Average Results } & $\mathbf{7 4 \%}$ & $\mathbf{5 2 \%}$ \\
\hline
\end{tabular}

The table above shows that the evaluation of participation and activeness of the students from the quality and quantity aspects. In the field of determination in carrying out the learning tasks, there are three sub indicators that have been rated. They are the activeness in doing tasks, the participation in submitting tasks, and the accomplishment in doing all tasks from the teacher. For this indicator, there are $73 \%$ students are determine in carrying out the tasks. Qualitatively, there is $61 \%$ of students' activeness in accomplishing the tasks from the teacher. The observer infers that students are assumed cannot understand well the teaching material since they cannot struggle from the learning difficulties. Moreover, many students are not discipline in the class so that they are moving around with the intention of finding helps from other students that gives negative contribution in the students' accomplishment in finishing the tasks.

In the aspect of students' persistence in fronting of difficulties, quantitatively, there are $80 \%$ of total students can survive in fronting learning difficulties, even though there are participation is shown in the level $40 \%$ by the students. Furthermore, the observer sees there is some students are showing their emotional behaviour to the other students since they are not accommodated by the other students since they ask for the direct answers from the tasks.

From the observation, the enjoy feeling of the students about the learning process is confirmed at $80 \%$ from the aspect of quantity. In the term of quantity of good feelings from the students, the observer rates at $60 \%$. The observer gives destructive motivation to the teacher in improving the teaching quality.

In terms of independence in learning, the students is described they have less initiation to find another teaching resources from other references such as dictionary or textbooks that has been provided to the students. In this occasion, it can be measured that 
there are $60 \%$ students actively looking for another teaching resources in solving their learning difficulties in order to accomplish the task from the teacher. Qualitatively, it shows that only $40 \%$ effort that they produce in showing their initiative for learning independently. The observer comments that the lack of students' initiation for independent learning is because the absence of better facilities and infrastructure to the students in getting the handbook or supplementary book and accessing internet for learning.

In the part of EFL learning desire, in term of numbers, it is shown that there are $77 \%$ students who are visible learning with vengeance. In term of quality of students' attitude, there are $60 \%$ the activeness that can be rated by the observer from over all teaching process in the first cycle. In the problem of students' motivation, there several things that is emphasized by the observer. Many students has lost their attention in the learning process so it gives impact for the understanding of the teaching material that has been presented by the teacher, even though there are some students are actively involved in class interaction. This situation makes most of students do not pay attention to teacher totally, since their attitude shows the note-taking activity is abandoned by most students instead of joking and laughing. Most students have less awareness to be organized in making interaction during the learning activities.

Post-test is set to the students in the end of learning activities as the medium of evaluation and confirmation of learning experience that have been done by the students in the first cycle. Post-test is created in form of written test that consist of blending between multiple-choice and matching. The results of students post-test in table below shows that $86 \%$ number of students fail in attaining SMA that is 75 points. The modus of the students score is in the range among $41-60$. It is assumed that the students' learning achievements from the all sequences scenario of the first cycle is failure due the low of average class score which is touching 44.38 points that gives the sign that it is far lower than SMA.

Range Score of Post-test Results in the First Cycles

\begin{tabular}{|c|c|c|c|}
\hline No. & Range Score & Frequency & Percentage \\
\hline 1. & $0-20$ & 4 & $25 \%$ \\
\hline 2. & $21-40$ & 3 & $19 \%$ \\
\hline 3. & $41-60$ & 7 & $44 \%$ \\
\hline 4. & $61-80$ & 2 & $13 \%$ \\
\hline 5. & $81-100$ & 0 & $0 \%$ \\
\hline \multicolumn{3}{|c|}{ Average Class Score } & $\mathbf{4 4 . 3 8}$ \\
\hline
\end{tabular}

The learning objective of the first teaching cycle is the fulfilment of SMA for the students that has been measured by conducted post-test. The findings show that there are only $13 \%$ of students that have score above SMA in learning EFL that is 75 points. It can be concluded that most of students cannot achieve SMA.

The students' failure after the post-test can be predicted by observing the finding in the two instruments before that is questionnaires and classroom observation. In the questionnaires findings the average number of positive responds of the students is about $67 \%$ over all students whereas the rest students suffers for the learning difficulties and lack of learning motivations after taking the first teaching cycle. In the term of classroom 
observation the $74 \%$ quality of students' activeness, participation, and learning motivation cannot lift the students' learning achievements. For that reasons, the most logical alternative in solve the students' achievements issue is to change the learning process to elearning process that is expected can increase students' perception, activeness, participation and motivation thus it can make positive impact directly to the better students' learning achievements.

The second teaching cycle is held in the next meeting with the same kind material that is reading comprehension with the different kind of text to be read. In this cycle the characteristic of the class from paper based learning that use paper and pen is changed into the learning that applying Edmodo as the media with the assistance of computer such as PC or smartphone that can access internet. For make it happens, it requires some preparations to build e-learning system based on Edmodo.

In applying Edmodo, at least there are three important things that should be prepared. The things that should be prepared are hardware, software, and the user itself. Hardware can be said that it is the most and fundamental in the preparation process. The hardware is divided into the hardware that is used in accessing the internet and the internet infrastructure itself. Now days, the hardware that used to access internet has been developed to be more practical by applying mobility principle. In this occasion, the hardware that use to access the internet that is suggested in order to accessing Edmodo are PC such as desktop, laptop, netbook and the mobile communication device such as android tablet till smartphone with various screen size. In accommodating the need of such kind of the device, the teacher asks the students to bring a device that can access internet that is self-belonging or borrow from other family members, friends as well as the school facility.

For the internet infrastructure, it is needed high speed and stable internet connection to accommodate all the students' device in accessing Edmodo. Generally, to connect with the internet, students can use their own cellular internet connection by using cable or Wi-Fi that they can transmit from their cell phone. It need more cost for the students, thus the researcher has initiative to make Wi-Fi network by using router to share the connection and modem to connect to internet in the classroom. By using the internet connection from the router, the students can utilize the connection in order to have access to Edmodo.

The software to accessing Edmodo mostly has been provided inside the device. The software that is the requirements is the internet browser. The example of the software of internet browser for instance Microsoft Edge ${ }^{\circ}$, Mozilla Firefox, Google Chrome, Safari, and so on. And the tips for the tablet or smartphone user, the setting of the browser should be in the desktop mode where is the entire website content is displayed in desktop version so that all of the Edmodo feature can be optimized without any obstacles.

In the user aspect, the teacher as well as the researcher has been trained the procedures in applying Edmodo from Digital Class Training that is held by SEAMOLEC before. From the experience form digital class in using Edmodo in various users, teacher's role and student's role, the researcher shares the knowledge around Edmodo to the students. By using sometime outside the learning hours, the researcher conducts a short socialization and training for students. The output of these socializations, students are expected to be independent starts from self-register to get Edmodo account until doing and submitting the tasks that has been posted thru Edmodo. 
In the second cycle, research posts two bundles of questionnaires that are answered by the students. The first questionnaire is given to the students when they are registering their self in Edmodo. This bundle of questioners is about the base information of students' preparation to use Edmodo. The questioner consists of the question that they should answer honestly, and they are convinced that their answer is known by themselves.

Questioners Results about Students Interaction with Internet

\begin{tabular}{|c|l|c|c|}
\hline No. & \multicolumn{1}{|c|}{ Item of questioners } & Most Results & Percentage \\
\hline 1. & Do you frequently access the Internet? & Often & $64 \%$ \\
\hline 2. & $\begin{array}{l}\text { How many Social Media accounts do you } \\
\text { have? }\end{array}$ & 1 & $37 \%$ \\
\hline 3. & $\begin{array}{l}\text { What is Social Media Accounts that you } \\
\text { frequently access? }\end{array}$ & Facebook & $69 \%$ \\
\hline 4. & $\begin{array}{l}\text { What devices often do you use to access } \\
\text { the internet? }\end{array}$ & $\begin{array}{c}\text { Internet Café } \\
\text { Computer }\end{array}$ & $48 \%$ \\
\hline 5. & What kind of connection you use often? & Cellular Connection & $41 \%$ \\
\hline 6. & $\begin{array}{l}\text { Have you assigned the school assignments } \\
\text { via the internet? }\end{array}$ & Seldom & $37 \%$ \\
\hline 7. & Do you know Edmodo? & Know Little & $50 \%$ \\
\hline 8. & Where did you know Edmodo from? & Teacher & $92 \%$ \\
\hline
\end{tabular}

The students convince that they often to use internet and have social media actively. It reveals that there are several students have more than one social media account. But mostly of them around 69\% frequently exist in using Facebook. They access the Facebook pages by using computers in the internet café until the smartphone that is belong to them with relying on cellular connection. Several students often use internet in order to help themselves in solving the homework and to send their assignments to their teacher. But their knowledge about Edmodo or website that similar of Edmodo is relatively unknown, except one student reveals that it is not new information.

From the results, it is assumed that the application of Edmodo can be adapted and accelerated by the students. With the practices, students are considered to operate Edmodo, start from posting questions, giving comments, submitting assignments, voting the polling until working the exercise and test in the form of quiz with various designs.

The table above describes that is more positive responds from the students than negative responds to the second teaching cycle. It is reflected that the level of students' learning motivation is assumed around $86 \%$ from overall students. It is declared that most students are ready to have digital class by applying Edmodo for them.

In the level of $86 \%$, the researcher feel optimized that it can give significance influence for the increasing of the students' learning achievements. The numbers can describes the level of students' participation in learning process and survive from the learning difficulties which they deal with. And it can be concluded more than $85 \%$ students in the classroom fell enthusiastic with the digital media that has been carried out. 
Questionnaires Results for the Second Cycle

\begin{tabular}{|c|l|c|c|}
\hline \multirow{2}{*}{ No } & \multicolumn{1}{|c|}{ Statements } & \multicolumn{2}{|c|}{ Students' Responds } \\
\cline { 2 - 4 } & & Positive & Negative \\
\hline 1. & I am happy to learn English with Edmodo & $95 \%$ & $5 \%$ \\
\hline 2. & $\begin{array}{l}\text { I love bringing the smartphone / tablet / laptop for } \\
\text { learning in school }\end{array}$ & $58 \%$ & $42 \%$ \\
\hline 3. & $\begin{array}{l}\text { I am actively commenting on Edmodo, especially } \\
\text { regarding the subject matter }\end{array}$ & $32 \%$ & $68 \%$ \\
\hline 4. & I feel quickly familiar with Edmodo & $89 \%$ & $11 \%$ \\
\hline 5. & $\begin{array}{l}\text { I feel pleased because my EFL learning materials stored } \\
\text { in my Edmodo }\end{array}$ & $100 \%$ & $0 \%$ \\
\hline 6. & I can stand for long time in Edmodo to learn EFL & $84 \%$ & $16 \%$ \\
\hline 7. & I feel happy if all the tasks can be done in Edmodo & $100 \%$ & $0 \%$ \\
\hline 8. & $\begin{array}{l}\text { I am able to communicate actively with teachers outside } \\
\text { class hours via Edmodo }\end{array}$ & $67 \%$ & $33 \%$ \\
\hline 9. & $\begin{array}{l}\text { Edmodo provides ample opportunity to develop my } \\
\text { learning ability }\end{array}$ & $95 \%$ & $5 \%$ \\
\hline 10. & Internet network makes me lazy to use Edmodo & $71 \%$ & $29 \%$ \\
\hline 11. & $\begin{array}{l}\text { Without a laptop, I can access Edmodo with my } \\
\text { smartphone }\end{array}$ & $83 \%$ & $17 \%$ \\
\hline 12. & $\begin{array}{l}\text { Time limit feature on Edmodo makes me learn to } \\
\text { discipline }\end{array}$ & $100 \%$ & $0 \%$ \\
\hline 13. & I was able to learn independently with Edmodo & $91 \%$ & $9 \%$ \\
\hline 14. & $\begin{array}{l}\text { I am happy to repeat the lessons that have been given } \\
\text { through Edmodo }\end{array}$ & $100 \%$ & $0 \%$ \\
\hline 15. & I am able to compete fairly with my friends via Edmodo & $100 \%$ & $0 \%$ \\
\hline 16. & $\begin{array}{l}\text { I am pleased Edmodo has much choice of quizzes form } \\
\text { that is very challenging }\end{array}$ & $100 \%$ & $0 \%$ \\
\hline 17. & $\begin{array}{l}\text { I feel my learning process is recorded by Edmodo can } \\
\text { help me to semester examinations }\end{array}$ & $96 \%$ & $4 \%$ \\
\hline 18. & $\begin{array}{l}\text { I'm happy because I do not have to carry a lot of books } \\
\text { and materials after Edmodo }\end{array}$ & $91 \%$ & $9 \%$ \\
\hline 19. & $\begin{array}{l}\text { I feel lucky to have been introduced to Edmodo by my } \\
\text { English teacher }\end{array}$ & $100 \%$ & $0 \%$ \\
\hline 20. & I want to learn other subjects with Edmodo & $65 \%$ & $35 \%$ \\
\hline & \multicolumn{1}{|c|}{ Average Responds } & $\mathbf{1 4 \%}$ \\
\hline & & & \\
\hline
\end{tabular}

For the indicator of determination in doing learning tasks, there are $93 \%$ students are on the right track in completing the task. Qualitatively, it is around $80 \%$ students' activeness that can be rated by the observer. In the aspect of persistence in struggling against learning difficulties, the numbers of students that are dare to survive and handling the problems rises to $80 \%$. It gives similar results on the quality of students' activeness. It is found that the enjoy feelings in learning EFL has maximum results both in students quantity and activeness quality. In the matter of independent learning, students is described 
that they do not give significance change to learn independently such as comparing or seeking the other material from various learning resources that out of the teacher preparation for instance books, dictionary or even internet that they can directly use it. The good news is, from the $80 \%$ students who show their activeness, they perform maximum effort in supporting their independent learning. Finally in the aspect of desire in learning EFL, it is $86 \%$ from all students show their seriousness in learning activities. The quality of their seriousness is at the point of $91 \%$ that has been rated by the observer during the second teaching cycle.

Observation Results of the Second Cycle

\begin{tabular}{|c|l|c|c|}
\hline No & \multicolumn{1}{|c|}{ Indicator } & $\begin{array}{c}\text { Quantity of } \\
\text { Activeness }\end{array}$ & $\begin{array}{c}\text { Quality of } \\
\text { Activeness }\end{array}$ \\
\hline 1. & Determination in carrying out the learning tasks & $93 \%$ & $80 \%$ \\
\hline 2. & Persistence in fronting of difficulties & $80 \%$ & $80 \%$ \\
\hline 3. & Good feelings towards learning EFL & $100 \%$ & $100 \%$ \\
\hline 4. & Independence in learning & $80 \%$ & $100 \%$ \\
\hline 5. & The strong desire to learn EFL & $86 \%$ & $93 \%$ \\
\hline & \multicolumn{1}{|c|}{ Average Results } & $\mathbf{8 8 \%}$ & $\mathbf{9 1 \%}$ \\
\hline
\end{tabular}

Overall from the classroom observation, the students are considered fulfilling the targets and objectives of learning in the second teaching cycle. They tend to be more active, more confidence, more discipline in doing the tasks and more enthusiastic with the learning content. They are active in solving their learning difficulties not only taking help from the textbook and dictionaries, but also they utilize themselves through the internet access that provide more various learning sources that are being in. the students' activeness is clearly observed by their significance attitude such as more active in questioning, giving opinions until helping their friends that are facing learning difficulties.

Range Score of Post-test Results in the Second Cycles

\begin{tabular}{|c|c|c|c|}
\hline No. & Range Score & Frequency & Percentage \\
\hline 1. & $0-20$ & 0 & $0 \%$ \\
\hline 2. & $21-40$ & 1 & $4 \%$ \\
\hline 3. & $41-60$ & 3 & $13 \%$ \\
\hline 4. & $61-80$ & 11 & $48 \%$ \\
\hline 5. & $81-100$ & 8 & $35 \%$ \\
\hline \multicolumn{2}{|c|}{ Average Class Score } & $\mathbf{8 2 . 6 1}$ \\
\hline
\end{tabular}

The post-test for the second teaching cycle is designed to be access via Edmodo. The projection of the table above describes that academically, there are still $17 \%$ of the students have the score below SMA. The modus of the scores are increasing to range score $61-80$ with the average class score at point 82.61 . 


\section{Comparison of Observation Results among Cycles}

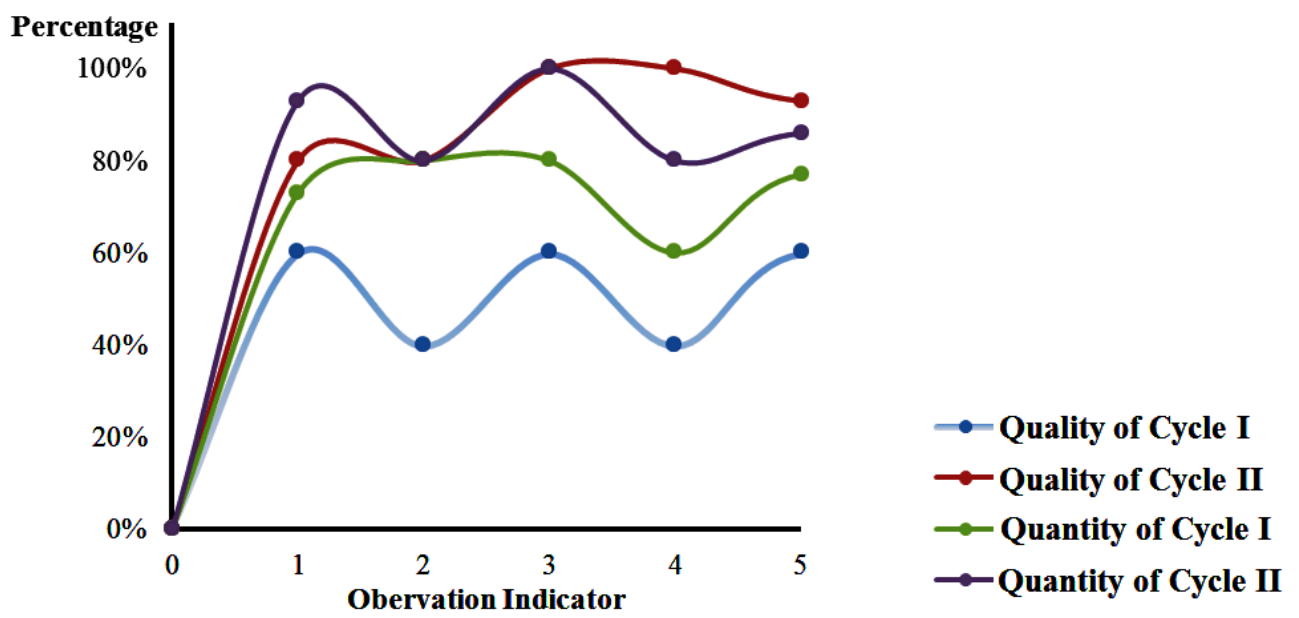

By comparing the finding among teaching cycles in each instrument, the positive movement of the students is clearly revealed. In the first cycle, the questionnaires give findings that students have $67 \%$ positive motivation in learning EFL. It is going affirmatively in the second cycle where the positive motivations of the students are getting $86 \%$ since the paperless leaning by using Edmodo is piloted. It is confirmed by observation instruments that are showing the positive association in terms of students' attitude, participation, activeness and autonomy. The changes of observation results briefly describe into figure below.

\section{Comparison Score among Cycles}

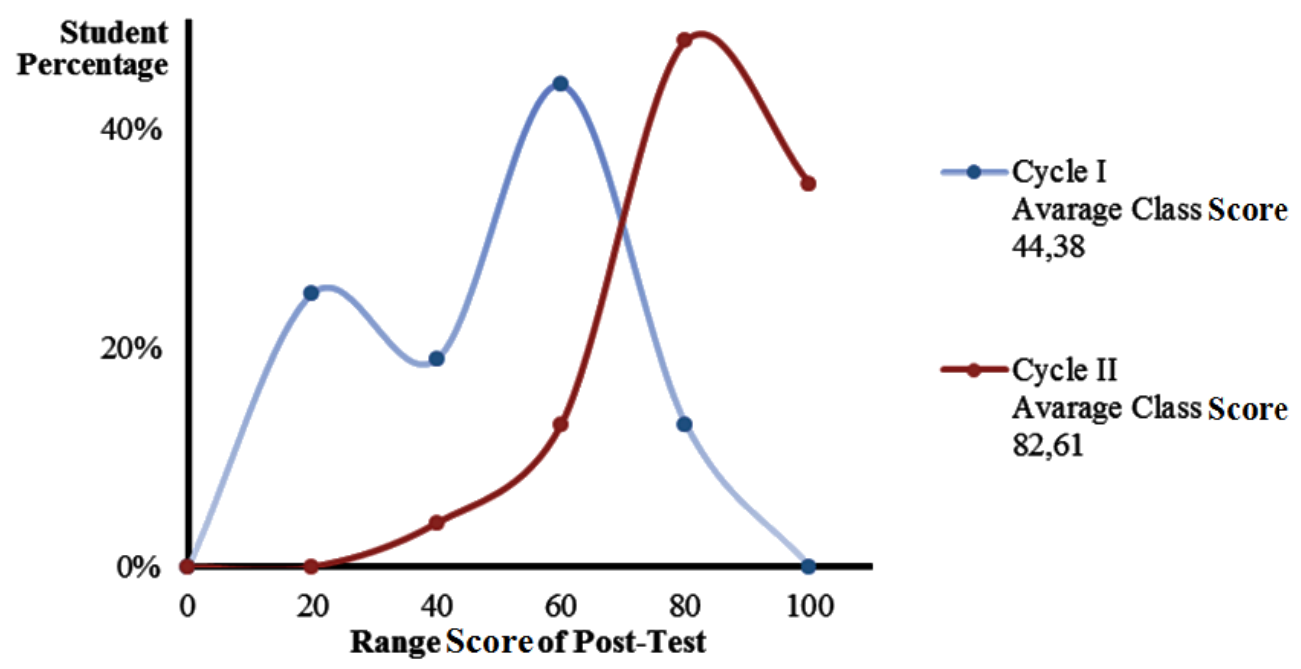


After the positive changes has been obtained in the two instruments before, by noticing the results post-test in the each of teaching cycles, it can be found that the positive trend is occurred in the students' post-test results. The changes start at the point 44.38 as average class score and it is going escalate almost two times in 82.61 points in the second cycle. The bad news is the results are reminding number of students who are failed in achieving SMA before and after using Edmodo. The fact confirms that the number of the failure students number are reducing form $88 \%$ to $17 \%$ as seen at figure below.

\section{CONCLUSION}

From the finding, it can be conclude to be two major consequences. The first conclusion is the results of the three instruments show the similar trend after using Edmodo in the classroom. The questionnaires display that the level of students motivation rise from $67 \%$ to $86 \%$. It is similar with what do observations result. The quantity of active students is increased $74 \%$ to $88 \%$ meanwhile the quality of students' activeness move from $52 \%$ to $91 \%$ among the cycles. Those two instruments are confirmed by post-test as quiz instrument that measuring students' learning achievement. The results of post-test escalate from 44.38 points to 82.61 points but leave $88 \%$ failure students in the first cycle and the number are reduced to $17 \%$ in the second cycle. Therefore, Edmodo as media in learning EFL has been established effective and efficient in increasing students' achievement in learning EFL particularly in reading comprehension class of eleventh grader in MAN 1 Ambon. Even though there are many things that should be improved in order to get the optimal results in getting the better effectiveness in teaching by using Edmodo.

The second conclusion is the problems that confront by the teacher in applying Edmodo are divided into three parts which are hardware problems, software problems and user problems. The problems in aspect of hardware, the issue is around the existence of computer device for the accessing internet and the internet connection availability. For the absence of device, students can find out by borrowing from the family members, friends, school's facilities, or by sharing computer among friends. For the internet connections, sharing via Wi-Fi is an alternative solution instead of using modems individually. Software problems are rarely found in the implementation, since devices in accessing internet has been implanted common software include internet browsers. Downloading the latest version of internet browser makes the better browsing experience. And the last problems is about user problems that can be happened either teachers or students. For the teacher, they can attend digital class training program, read related reference about optimization in using Edmodo, join the digital class discussion, and finally practice the information that has been got. The skilled teacher can easily guide the students in order to using Edmodo properly.

Based on the conclusion above, there are several suggestions that can be shared to the schools, teachers, and students. For schools, the procurement for standardized learning infrastructure should be oriented to advanced digital learning technology in assuring the prime service for the students, where technology is common issue now days. The human resources development of the teachers by schools should be emphasized in order to increase teacher's competencies toward paperless school. It is expected that the teachers can open by themselves for admit the rapid technology improvement with the intention of supporting learning process. They can promote their competences by following professional organization, attending scientific forum, and participating seminars or trainings in 
educational technology. The students that have computer devices from smartphone to personal computer should employed those devices in assisting learning activities and always applying ethics in using those devices and internet. And student should be active in giving their constructive opinion about their learning difficulties.

From this research, the research development can be followed up since the maximum affectivity of Edmodo in this research cannot be reach. Basically, this research recommends for the teachers to use this media either in the classroom or open distance learning, for either learning process or testing process. For the future research, the next researcher can combine Edmodo with new ideas so that can make better improvement in the results. The comparative study can be conducted in order to find the strength and weakness of the other e-learning media. Furthermore, the duration of the research can be expanded thus it can gaining more reliability and objectivity of research findings

\section{REFERENCES}

Adnan, Sitti Masyithah, Ohoiwutun, Jos E, \& Shalehuddin. (2016). Improving Reading Comprehension of The Eighth Grade Students Through Just-In-Time Teaching Technique. ELTS JOURNAL, 4(1), pp. 1-12.

Amiroh. (2012). Kupas Tuntas Membangun E-Learning dengan Learning Management System Moodle Ver. 2. Sidoarjo: Genta Group Production.

Brown, H. Douglas. (2001). Teaching by Principles : An Interactive Approach to Language Pedagogy (2nd ed.). New York: Longman.

Chapelle, Carol. (2003). English Language Learning and Technology : Lectures on Applied Linguistics in The Age Of Information and Communication Technology. Philadelphia: John Benjamins Pub.

Hastomo, Tommy. (2016). The Effectiveness of Edmodo to Teach Writing Viewed From Students' Motivation. Paper presented at the Proceeding of International Conference on Teacher Training and Education.

Heaton, J. B. (1989). Writing English Language Tests. London: Longman.

Juliani, A. J. (2015). Inquiry and Innovation in The Classroom : Using 20\% Time, Genius Hour, and PBL to Drive Student Success. New York: Routledge.

Kemmis, Stephen, McTaggart, Robin, \& Nixon, Rhonda. (2014). The Action Research Planner : Doing Critical Participatory Action Research. Singapore: Springer.

Mettetal, Gwynn. (2003). Improving Teaching through Classroom Action Research. Essays on Teaching Excellence, 14(7).

Noviana, Okke, Rufinus, Albert, \& Bunau, Eusabinus. (2015). The Effective Use of Edmodo in Writing a Narrative Text in Senior High School. Jurnal Pendidikan dan Pembelajaran, 4(11).

Rismayanti, Anti. (2013). Pembelajaran Simulasi Online. In G. Priowirjanto \& Y. Prapantja (Eds.), Materi Simulasi Digital. Jakarta: SEAMOLEC. 